\title{
Clinical and Psychological Aspects of the Bereavement and Diagnostic of Complicated Grief
}

\section{Клініко-психологічні аспекти переживання втрати та діагностики ускладненого горювання}

\author{
Oleksandr Avramchuk \\ Ph.D. in Psychology, \\ Assistant Professor
}

\author{
Олександр Аврамчук \\ кандидат психологічних наук, \\ доцент
}

E-mail: avramchuk.md@ucu.edu.ua orcid.org/0000-0001-8512-7817

Researcher ID: A-7595-2019

Clinical Psychology Department, Ukrainian Catholic University, Lviv, Ukraine

17, Il. Svientsitskoho str., Lviv, Ukraine, 79000
Кафедра клінічної психологї,

Український католицький університет, л. Львів, Украӥна вул. Іл. Свєнціцького, 17, м. Львів, Україна, 79000

Original manuscript received April 17, 2019

Revised manuscript accepted May 14, 2019

\section{ABSTRACT}

The actual studies of scientific and psychological approaches to the concept of experiencing bereavement and complicated grief are considered in the article. It is emphasized that the optimal trajectory of recovery after the death of a significant person consists in the successful resolution of nonlinear "tasks", caused by the loss, and passes with minor functional impairments, involves effective coping strategies and activities that allow a healthy way of expressing emotions, remembering the deceased and overcome current life problems.

The information on clinical and psychological features and diagnostic signs of complicated grief are generalized. It is proved that the core of the complicated grief is a complex of symptoms of intense and persistent sepa- 
ration distress, which does not lead to the elaboration of the experience of loss, but is replaced by stereotyped, repeated thinking strategies and behavior strategies, which increase psychosocial disturbances. The diagnostic criteria for the difference between healthy and pathological (complicated) grief, covering the intensity, duration, and complexity of symptoms are identified. The relevance and complexity of the differential diagnosis of complicated grief among other bereavement-related mental health disorders are emphasized. It is noted that due to the communion of a clinical picture with a major depressive disorder and post-traumatic stress disorder, people with complicated grief remain inadequately diagnosed or misdiagnosed, and that leads to the using of treatment as usual that partly reduces comorbid symptoms without affecting the complicated grief symptoms. The differences between complicated grief, major depressive disorder, and post-traumatic stress disorder are generalized, which may be useful for differential diagnosis by mental health professionals.

The author concluded that there is a need to develop educational and training programs directed at increasing professional knowledge and competencies in diagnostics and differential diagnostics of complicated grief and adaptation of screening methods for assessing complicated grief in Ukraine.

Key words: bereavement, the process of grieving, complicated grief, depression, PTSD.

\section{Вступ}

Горювання - процес, який слідує за втратою (смертю) близької людини й традиційно сприймається як універсальна та нормальна реакція. Інтерес науковців і практиків до полегшення процесу горювання у людей, які переживають втрату, зростає, що, у свою чергу, вимагає перегляду актуальних знань і практичних рекомендацій щодо психосоціальної підтримки. Дослідження психічного стану людей, які пережили втрату, та, зокрема, процесу горювання відзначено у багатьох працях як психоаналітичних, так і когнітивних і феноменологічних напрямків і вчень.

Актуальним викликом для фахівців є проведення диференційної діагностики між нормальним (звичним) для традицій, культури та досвіду горюванням i процесом ускладненого горювання. Водночас виникає потреба вирізняти ключові ознаки ускладненого горювання поміж 
інших адаптивних i дезадаптивних реакцій на втрату близької людини, які можуть стати ціллю психотерапії чи інших психосоціальних заходів (Аврамчук, 2018).

Залежно від критеріїв, поширення ускладненого горювання як самостійної нозології зустрічається серед 2-3\% населення в усьому світі: R. Rosner посилається на дослідження, опубліковані за період 2008-2011 pp., указуючи на коливання показника у діапазоні 2,4-4,2\% (Rosner, Pfoh \& Kotoucova, 2011). M. K. Shear і співавтори наводять цифру поширення симптомів ускладненого горювання у 10\% (Shear et al., 2011). Схожі показники були озвучені G. A. Bonanno та колегами ще у 2007 p. (Bonanno, Neria, Mancini et al., 2007), із зазначенням, що рівень поширеності може бути більший - до $15 \%$, коливання у межах 10-15\% згадується у статті M. R. Thompson і співавторів (2017).

Як показали дослідження, досвід ускладненого горювання викликає суттєві, стійкі дискомфорти та порушення впродовж багатьох місяців або років (Boelen \& Prigerson, 2007; Shear et al., 2011; Zisook et al., 2012; Duffy \& Wild, 2017). Частина ж людей продовжує жити й не усвідомлює, що їх поведінка, емоційні зміни та прийняті рішення під впливом негативних думок, що заважають нормальному функціонуванню, - результат непережитої втрати. Тому люди з ускладненою реакцією на втрату залишаються недіагностованими, чи хибно діагностованими за такими станами та розладами, як великий депресивний розлад, посттравматичний стресовий розлад (далі - ПТСР), спектр тривожних розладів або їх комбінації (Lichtenthal, Cruess \& Prigerson, 2004; Boelen \& Prigerson, 2007; Simon et al., 2007; Jordan \& Litz, 2014; Zisook et al., 2014; Guldin, 2015). У зв'язку з цим, на нашу думку, згаданий вище відсоток поширеності дещо занижений, оскільки, відчуваючи увесь спектр дискомфорту, люди, які зазнали тяжкої втрати, часто не звертаються за допомогою. Це впливає на виявлення клінічних ознак, не зважаючи на суттєве погір- 
шення психосоціального функціонування особистості та високий ризик негативних наслідків, зокрема суїцидальної поведінки. Актуальності також додає те, що втручання, спрямовані на первинну профілактику, не зменшують можливість виникнення ускладненого горювання у людей, які зазнали втрати, а застосування типового медикаментозного лікування, що передбачає використання антидепресантів як базової лінії терапії, все частіше стає однією з найрозповсюдженіших практик (Wittouck, Van Autreve, De Jaegere, Portzky \& van Heeringen, 2011). Водночас дані мета-аналізів і рандомізованих, контрольованих досліджень показують ефективність психотерапії як першої лінії вибору при лікуванні ускладненого горювання (Shear et al., 2005; Rosner et al., 2011; Shear et al., 2014; Bryant et al., 2014; Shear et al., 2016).

Мета статті - розглянути клініко-психологічні особливості переживання втрати й ускладненого горювання та проаналізувати стан розробки цієї проблеми у сучасних психологічних дослідженнях.

\section{Завдання статті}

1. Здійснити теоретико-методологічний аналіз підходів до розуміння процесу переживання втрати й ускладненого горювання.

2. Розширити знання фахівців у сфері психічного здоров' я щодо клініко-психологічної діагностики нормального й ускладненого горювання.

3. Ідентифікувати подібні та відмінні аспекти клінічної картини ускладненого горювання, великого депресивного розладу та посттравматичного розладу.

\section{Методи та методики дослідження}

Для аналізу науково-дослідницьких джерел у дослідженні було використано теоретичні методи. За допомогою системного аналізу літератури було проаналізовано теоретико-методологічну базу процесу переживання втрати й 
ускладненого горювання. Пошук попередніх досліджень, пов'язаних із темою статті, здійснювався через PubMed, Medline, Web-of-Science, BIOSIS, Cochrane library and Research Gate. Для огляду актуальних досліджень увагу було зосереджено на статтях, опублікованих не пізніше, ніж 10 років тому, а об'єктом дослідження визначено клініко-психологічні аспекти ускладненого горювання. Пошук здійснювався за такими ключовими словами: "ускладнена реакція на втрату»; «ускладнене горювання»; «патологічне горе»; «патологічне горювання»; «complicated grief disorder»; «bereavement-related disorder»; «complex bereavement disorder» .

Вибір такого методу дав змогу проаналізувати актуальні знання щодо процесу переживання тяжкої втрати; визначити структуру й особливості проявів ускладненого горювання; розкрити та синтезувати виявлені особливості диференційної діагностики ускладненого горювання; сформулювати висновки за результатами дослідження й окреслити перспективи подальших досліджень.

\section{Результати та дискусії}

У своїх працях S. Freud процес переживання втрати «роботу горя»- розглядав як складний і тривалий процес, спрямований на пошук і побудову нових життєвих цілей, цінностей і значень без померлого (Malkinson, 2010). «Робота горя», на думку S. Freud, може тривати від 6 до 12 місяців. M. I. Лім, аналізуючи працю S. Freud «Сум і меланхолія» (1917 р.), вказує, що погляди психоаналітика на «роботу горя (суму)» полягають у тому, щоб «відірвати психічну енергію» від значимого, але вже втраченого об'єкта, й у кінцевому результаті стати вільним від прив'язаності до нього та мати сили скерувати цю психічну енергію на інші об’єкти, які стануть значимими (Лім, 2010). Автор статті слушно зауважує, що у праці S. Freud процес горювання розглядається як процес забування, проте, на думку М. I. Лім, процес горювання - це «...не відрив енергії від 
втраченого об’єкта, а усунення образу цього об’єкта для збереження в пам'яті» (Лім, 2010: 162). У 1944 р. E. Lindemann у статті «Symptomatology and management of acute grief» описав клінічну картину стану «гострого горювання» як універсального клінічного синдрому з характерною психологічною та соматичною симптоматикою, що є проявом стану надмірної залежності від значимої особи (Lindemann, 1944). E. Lindemann зазначає, що клінічна картина такого стану може змінюватися залежно від часу й того, наскільки успішно людина здійснює «роботу горя», згадану в працях S. Freud.

Першу, стадійну, модель переживання втрати частіше ідентифікують за працями E. Kübler-Ross, уперше опублікованими у 1969 р. Відповідно до теоретичних напрацювань авторки, процес горювання вміщує п'ять узагальнених стадій, названих відповідно до ключових емоційних і когнітивних компонентів, що їх супроводжували: заперечення, гнів, перемовини (пошук компенсації), депресія та прийняття (Beckett \& Dykeman, 2017). Л. Б. Наугольник зазначає, що коли людина підготовлена до факту втрати (навіть якщо виказує сильні болісні почуття), то перехід між стадіями чи етапами цього процесу стає розмитим i непомітним (Наугольник, 2015). Однак, як стверджують C. Beckett i C. Dykeman, посилаючись на низку досліджень, ця теорія, незважаючи на їі популяризацію, не знайшла емпіричного підтвердження (Beckett \& Dykeman, 2017). Критиці також піддана ідея надмірного узагальнення стадій, неврахування особливостей культури й індивідуального попереднього досвіду та формування стереотипного мислення / погляду серед фахівців сфери психічного здоров'я на людей, які переживають втрату. Водночас теоретична основа, закладена працями E. Kübler-Ross, дала змогу сформувати алгоритми та керівництва психологічної самодопомоги, беручи за основу зрозумілу й просту для психоедукації модель і конкретні цілі, що досягаються кожною стадією. 
До розгляду процесу горювання як змінних, послідовних фаз також відносять праці різних команд дослідників під керівництвами J. Bowlby, C. M. Parkes i C. M. Sanders (Bowlby, 1980; Beckett \& Dykeman, 2017). J. Bowlby, спираючись на авторську теорію прив'язаності, виокремив чотири послідовні фази: фазу оніміння, фразу туги та сепараційної тривоги, фазу відчаю та дезорганізованості й фазу повторного повернення (входження) до життя (Bowlby, 1980). Автор визначав горювання як систему поєднання відчаю та смутку в контексті сепараційного синдрому, а тому приділив вагоме значення втраті стосунків, соціального статусу та ролей, навіть мрій, що були пов'язані зі значимою особою. Теорія втрати С. M. Parkes описує «попередньо запрограмовані» набориповедінкових реакцій, спрямованих на опанування втрати: оніміння, пошук («втраченого об'єкта». - Прил. автора) і тужіння, депресія, відновлення. Схожу послідовність пропонуе С. M. Sanders та її колеги, які виокремили таку послідовність: фаза шоку, фаза усвідомлення втрати, фраза віддалення (відчуження, анулювання), фаза зцілення та відновлення. Авторка зробила акцент на внутрішніх і зовнішніх підтримуючих чинниках, згадуючи, що вік, стать та інші чинники по-різному можуть впливати на процес горювання. Водночас, звернувши увагу на те, що сам по собі процес горювання, «застиглий у часі», також може бути шкідливим і травматичним для людини. Запропоновані теоретичні моделі допомагають зробити важливий висновок: якщо процес переживання втрати не опрацьовується на певній стадії (у відповідний період) і людина застряє на одній із них, це призводить до емоційних порушень і фізичних проблем зі здоров'ям у подальшому.

Остання модель - модель «завдань» з'явилася у 80-90-х роках минулого століття й розширюється донині. До цієї групи відносять праці J. Worden, розширені у роботах T. A. Rando, M. S. Stroebe та H. Schut, i R. A. Neimeyer (Beckett \& Dykeman, 2017; Worden, 2018). Спільним для 
цих напрацювань є погляд на процес горювання не як послідовних стадій чи фаз, через які має пройти людина, а як комплекс нелінійних реакцій, відповідних життєвим завданням, які мають бути вирішені. Також ставиться акцент на тому, що цей процес немає чіткого завершення й може тривати упродовж тривалого часу, оскільки відображає поступові зміни, пов'язані з втратою значимого об'єкта. На думку О. В. Диси й О. Л. Василюк (2016), запропоновані моделі «завдань», а не лінійних стадій чи фаз, мають ширше клінічне застосування і є зручнішими для практичних фахівців, які надають психосоціальну підтримку людям, які переживають втрату, та їх оточенню. Повертаючись до змісту моделі, запропонованої J. Worden (Worden, 2018), то перед людиною, яка переживає втрату значимої особи, постає чотири основні завдання, які вона повинна вирішити, щоб перейти від горювання до відновлення: визнання того, що втрата реальна; переживання й опрацювання болючих думок і емоцій, пов'язаних з об'єктом втрати; адаптація до світу й нових умов життя без людини, якої вже немає; закріплення цих змін. Оригінальна назва останньої фази, доповненої автором через 20 років від першої публікації, звучить так: «Знайти спосіб, щоб згадувати померлого посеред решти, подорожуючи своїм життям» (Worden, 2018). Окреслені вище життєві завдання (та їх еквіваленти у суміжних теоріях) спрямовані на визнання втрати як такої й усвідомлення її ознак, наслідків, що дає поштовх для подальшого прийняття. Конфронтація болючим переживанням має на меті знизити відчуженість, сприяти переосмисленню втрачених стосунків, відмовившись від старої прив' язаності, сформувати новий досвід, який перебудується у нові стосунки, значення, способи сприйняття, та переспрямувати внутрішню енергію у досягнення й шляхи розвитку. Водночас «життєві завдання» для шляху горювання не є заздалегідь визначеними й формуються відповідно до внутрішніх чинників і зовнішніх, модифікуючих 
особливостей життєвої ситуації загалом. Такі погляди на переживання втрати роблять процес нормального горювання інтегрованим, гнучким й орієнтованим на клієнта, у той час як відмова від подолання життєвих завдань чи ригідна фіксація на одному з них робить цей процес патологічним, а горювання ускладненим.

B. J. Arizmendi та M.-F. O’Connor, проаналізувавши дані наукових джерел, дійшли висновку, що процес горювання людини, яка пережила важку втрату, може розвиватися за 4-ма траєкторіями:

- шляхом здатності відновлювати попередній психічний стан (англ. "psychological resilience»- процес адаптації й відновлення після смерті значимої людини з несуттєвими функціональними порушеннями та залученням ефективних копінг-стратегій і діяльності, що дають змогу проявляти емоції, згадувати померлого й долати поточні життєві проблеми);

- шляхом подолання депресії (процес, який за змістом наближений до концепції стадії «депресії» у працях E. Kübler-Ross, включає використання можливості подолання проявів дистресу й депресії як рушійної сили на шляху відновлення після втрати. Люди, які обрали таку стратегію, свідчать про використання спогадів про померлого для підвищення власної мотивації досягнення у майбутньому, пошуку позитивного значення подолання втрати для подальшого життя та відчувають полегшення від завершення «важких» стосунків);

- шляхом формування хронічної депресії (на відміну від попереднього варіанту, перебіг процесу горювання поглиблює ознаки клінічної депресії. Цей стан також отримав клінічне визначення як «депресія, асоційована (пов'язана) з тяжкою втратою» і призводить до стійких емоційних і фізичних порушень, порушень соціального функціонування, характерних для тяжких і хронічних форм депресії. Зазвичай, такий варіант типовий для людей, анамнез котрих об- 
тяжений афективними розладами, і тому стан більше пов’ язаний із нейробіологічними порушеннями настрою, ніж самою втратою);

- шляхом формування хронічного (ускладненого) горювання як самостійного психічного розладу (Arizmendi \& O’Connor, 2015).

Як зазначає J. Wetherell, у науковій літературі можна зустріти кілька синонімічних назв «ускладненого горювання» (Complicated grief): тривале горювання, хронічне горювання, травматичне горювання, патологічне горювання, узагальнених у клінічних нозологіях у MKБ-11 і DSM-5 (Wetherell, 2012). Аналізуючи історичні витоки терміна «ускладнене горювання" (Complicated grief), R. Rosner указує, що він як сформована нозологічна дефініція зустрічається у працях Horowitz i колег із 1997 p., до цього у дослідженнях науковців під керівництвом H. Prigerson цей феномен було клінічно виведено з варіантів клінічної картини афективних порушень, а в 1999 р. термін став використовуватися як «травматичне горювання» (Rosner et al., 2011; Thompson, Whiteman, Loucks \& Daudt, 2017).

На даний час ускладнене горювання розглядається як інтенсивне відчування горя, що не призводить до асиміляції досвіду втрати, а замінюється стереотипними, повторюваними стратегіями мислення та поведінки, які посилюють психосоціальні порушення (Malkinson, 2010). До варіантів таких стратегій емоційного й поведінкового реагування може бути віднесено прагнення залишити усе, як було до смерті близької людини, чи то у справах, чи речах, у такий спосіб очікуючи на їі повернення. Н. В. Онищенко розглядає подібні стратегії емоційного й поведінкового реагування як варіанти патологічної форми заперечення у структурі тривалого горювання, що призводить до неприйняття змін у житті людини, зупинення у власній жалобі (Онищенко, 2012). Слід зазначити, що частина людей, які пережили втрату, можуть заперечувати емоції, характер- 
ні для процесу горювання, впродовж тривалого часу. За результатами дослідження, описаними у статті Н. В. Онищенко, така тенденція більш характерна для чоловіків (Онищенко, 2012). Наведені вище дані доповнює дослідження, проведене S. Cochran у 2006 р., за результатами якого автор указує на те, що жінки частіше забороняють собі відчувати гнів стосовно померлого, разом із цим, чоловікам доводиться протистояти забороні на сум і тугу (Cochran, 2006). Власний досвід психотерапевтичної роботи із сім'ями загиблих у зоні проведення АТО дає підстави стверджувати, що відсутність характерних проявів горювання родичами й оточенням іноді може сприйматися як емоційна стійкість, без підозри на розвиток можливих проблем психічного здоров'я у майбутньому.

На думку М. І. Лім, до хворобливих реакцій горя (автор статті не розглядає час появи чи тривалість реакцій від моменту тяжкої втрати як критерії, що визначають «патологічність» процесу горювання, проте, на нашу думку, варто наголосити, що ці ознаки стають клінічно значущими у діагностиці ускладненого горювання по завершенню, щонайменше, 6-місячного терміну після втрати) можуть бути віднесені: відтермінування реакції; почуття нереальності; поглиненість образом померлого та /або так звана «невротична ідентифікація з померлим» (розглядається варіант поведінки, коли людина займається діяльністю, якою займався померлий); поява зорових і слухових образів померлого; поява симптомів захворювань, на які страждав померлий, у тому числі психосоматичних; зміна ставлення до навколишнього середовища і стосунків із родиною та друзями; підвищена збудливість, яка проявляється через роздратування, злість, бажання, щоб «не чіпали», ворожість до певних осіб чи інституцій; прогресуюче погіршення соціальної активності; почуття малоцінності, самозвинувачення; поведінка, спрямована на самопокарання чи заподіяння собі шкоди (Лім, 2010). 
Варто було б зазначити, що тривалий час симптоми «ускладненого горювання» не були включені до класифікаційних систем, а, відповідно, не розглядалися частиною клініцистів і фахівців у сфері психічного здоров'я як самостійний стан, який вимагає іншого погляду на проблему та відповідних інтервенцій. У сучасних дослідженнях усе частіше починають обговорювати й розглядати «ускладнене горювання» як самостійну нозологію, тобто розлад психічної діяльності (Prigerson et al., 2009; Boelen et al., 2010; Bryant et al., 2014; Lundorff et al., 2017). Як окрема нозологія такий стан характеризується вираженими симптомами горювання, що тривають не менше ніж півроку після втрати й призводять до суттєвих погіршень загального функціонування людини (Prigerson et al., 2009).

M. K. Shear та її колеги запропонували кластер симптомів інтенсивного і стійкого сепараційного дистресу визначити як основне ядро процесу ускладненого горювання (Shear et al., 2011). У такий спосіб людина має відчувати один або більше з таких чотирьох дискомфортних симптомів: 1) стійке, інтенсивне прагнення «бути 3 померлим»; 2) часті й інтенсивні періоди почуття самотності або порожнечі; 3) стійкі негативні думки про подальше життя без померлого або рецидивуючі висловлювання думок «приєднатися до померлого»; 4) тривожні, нав’язливі думки й згадування самого померлого, які погіршують щоденне функціонування. Характерні зміни психічного благополуччя включають сильну тугу, нудьгу або емоційний біль, почуття зневіри чи нездатності прийняти можливі труднощі / перешкоди майбутнього, труднощі у взаємодії з соціальної чи іншої діяльності, «соціальний аутизм» і відчуття, що життя не має сенсу, зростання вживання тютюну, алкоголю та інших психоактивних речовин, а також збільшення суїцидальних думок.

H. G. Prigerson і колеги у 2009 р. запропонували критерії до DSM-5, серед яких зазначили ключові симптоми 
нового клінічного діагнозу «тривалий розлад горювання» (Prigerson et al., 2009).

Критерій А: подія - втрата.

Критерій В: сепараційний дистрес проявляється щодня або призводить до порушень функціонування.

Критерій С: п'ять (або більше) з перелічених когнітивних, емоційних і поведінкових симптомів проявляються щодня або призводять до порушень функціонування:

1) відчуття збентеження щодо своєї ролі у житті або почуття «зменшення» / «спустошення» власної особистості (відчуття того, що частина самого себе померла);

2) складність прийняття втрати;

3) уникнення нагадування про реальність втрати;

4) нездатність довіряти іншим після втрати;

5) гіркота або гнів, пов'язані з втратою;

6) складність переходу до життя (наприклад, залучення нових друзів, переслідування інтересів);

7) відсутність емоцій або емоційна нечутливість із моменту втрати;

8) відчуття того, що життя стало порожнім або безглуздим після втрати;

9) почуття приголомшення або шоку.

Критерій D. Діагностика не повинна проводитися, поки не мине, щонайменше, 6-місячний термін після смерті.

Критерій Е. Порушення викликають клінічно значущі негаразди в соціальних, професійних або інших важливих сферах функціонування (наприклад, домашні обов'язки).

Критерій F. Порушення не можуть бути пояснені клінічною картиною великого депресивного розладу, генералізованого тривожного розладу або посттравматичним стресовим розладом.

У подальшому, на основі емпіричних досліджень команд під керівництвом M. К. Shear i H. G. Prigerson, до DSM-5 додано новий клінічний діагноз: Persistent Complex Bereavement (Bereavement-Related) Disorder (стійкий комплексний розлад, пов'язаний із тяжкою втратою), а 3 
2015 р. рекомендовано включення до MКХ-11: Prolonged grief disorder (тривалий розлад горювання). Варто зазначити, що у 2013 р. ця нозологія була включена до DSM-5 з приміткою: «розлад для подальших досліджень» (O’Connor et al., 2019). Водночас створення універсальних критеріїв діагностики й досі викликає дискусію, чи варто патологічний перебіг процесу горювання у першу чергу визначати як тривалий, з огляду на тривалість симптомів від моменту втрати, або комплексний, через прогресування й інтенсивність симптомів від моменту втрати (Duffy \& Wild, 2017). Результати останніх досліджень показали, що відмінності між двома нозологічними дефініціями за своєю суттю лише семантичні, а єдиним відмінним критерієм залишається пропонована мінімальна тривалість цих симптомів (відповідно, 6 місяців за MКХ-11 і 12 місяців за DSM-5), оскільки обидва діагнози емпірично засвідчили однакову прогностичну валідність і високі показники відповідності об'єкта діагностики (Maciejewski, Maercker, Boelen \& Prigerson, 2016; Lundorff et al., 2017; O’Connor et al., 2019).

Базуючись на клінічних критеріях, із метою ефективного диференціювання нормального та патологічного горювання M. Duffy та J. Wild (2017) пропонують використовувати такі діагностичні інструментарії: Inventory of Complicated Grief measures maladaptive responses to loss (Prigerson et al., 1995), Grief Cognitions Questionnaire (GCQ; Boelen \& Lensvelt-Mulders, 2005), Typical Beliefs Questionnaire (Skritskaya et al., 2017) i Grief Cognitions Questionnaire for Children (GCQ-C; Spuij et al., 2017).

Говорячи про клініко-психологічні особливості та прояви цього стану, слід указати, що уникнення соціальних контактів, як і формування уникаючої поведінки загалом, є типовою стратегією людей, які пережили втрату. Зниження бажання відвідувати певні місця чи перебувати у певних соціальних ситуаціях допомагає уникати болісних почуттів, пов'язаних зі спогадами про значиму особистість. Водночас, такий стан часто інтерпретують у кон- 
тексті симптомів клінічної депресії, пов’язаної з втратою, поряд із пригніченим настроєм, втратою зацікавленості, зниженням самооцінки та почуттям провини, а не як самостійний психопатологічний стан. L. Dell'Osso та колеги на основі власного емпіричного дослідження визначили коморбідність ускладненого горювання з клінічно значимими ознаками депресії у людей, які переживають тяжку втрату, вищу за 70\%, що також знайшло підтвердження у проаналізованих авторкою попередніх дослідженнях (Dell'Osso et al., 2011).

S. Zisook i його колеги, провівши низку емпіричних досліджень, зазначили, що депресія, пов'язана зі смертю близької людини, за клінічною картиною не відрізняється від «великого депресивного розладу», відповідно до критеpiïв DSM-5 (Zisook et al., 2012). Прояви депресії у людини, яка пережила тяжку втрату, характеризуються схожими особливостями у проявах і поведінці особистості, структуpi супутньої (коморбідної) патології, а очікуваний перебіг буде хронічним та / або рецидивуючим, водночас очікувалося, що вони аналогічно реагуватимуть на лікування антидепресантами (Zisook et al., 2012). Однак, як показали подальші дослідження, рекомендовані тактики лікування депресії (у тому числі психотерапевтичні інтервенції, акцентовані лише на симптомах депресії) мінімально впливають на прояви ускладненого горювання, хоча й зменшують притаманну депресії симптоматику (Bryant et al., 2014). Висновки рандомізованих контрольованих досліджень свідчать про те, що антидепресанти (зокрема, СІЗ3С, селективні інгібітори зворотного захоплення серотоніну) не ефективні щодо зниження тяжкості симптомів ускладненого горювання, тим не менш, можуть використовуватися як доповнення до психотерапії (Jordan \& Litz, 2014; Shear et al., 2016). Такі результати досліджень підтверджують гіпотезу про те, що великий депресивний розлад та ознаки депресії, коморбідні ускладненому горюванню, мають різні етіологічні чинники (Arizmendi \& O’Connor, 2015). 
Актуальні емпіричні дослідження вказують на зв'язок між вразливістю людей до формування ускладненого горювання та стилем прив'язаності у дитинстві (як свого часу зазначав Ј. Bowlby та його колеги), що обумовлює схожість проявів сепараційної тривоги у дорослих із клінічними проявами ускладненого горювання (Dell'Osso et al., 2011). Серед поширених тривожних розладів найбільшу коморбідність з ускладненим горюванням помічено для генералізованого тривожного розладу та панічного розладу з / без агорафобії (Simon et al., 2007). Як зазначено у дослідженні групи вчених під керівництвом N. Simon (2007), наявність коморбідностей у вигляді тривожних розладів погіршує перебіг процесу горювання, а саме помітно погіршує загальне функціонування, загострює проблеми зі сном і стає причиною виникнення вторинної депресії чи загострення травматичного досвіду з минулого, що опосередковано збільшує ризик суїцидальних спроб. Водночас за низкою інших проявів (зв'язок із травматичною подією, шокові реакції, інтрузивні спогади, відчуття безпомічності, уникнення нагадувань, відчуття провини того, хто вижив / продовжує жити) цей стан ближчий до посттравматичного стресового розладу, що призводить до акцентування психотерапевтичних втручань на травматичних спогадах і їх опрацюванні (Duffy \& Wild, 2017).

Узагальнюючи проаналізовані дані, ми зосередили увагу на відмінностях між ускладненим горюванням, великим депресивним розладом (відповідно до MКX-10: F32 - депресивним епізодом) і посттравматичним стресовим розладом (MКX-10: F43.1) як психічних розладах, які у першу чергу потребують диференційної діагностики у випадку переживання тяжкої втрати. На основі проведеного аналізу сучасних психологічних і психіатричних досліджень слід зазначити таке:

- для ускладненого горювання засмученість і пригнічений настрій пов'язані з розлукою й думками про померлих, у той час як для епізоду клінічної депресії важливим 
патогенетичним елементом $€$ зв'язок настрою з песимістичними й надмірно узагальненими румінаціями (непродуктивне, циклічне мислення, сфокусоване на абстрактних питаннях без відповіді) щодо більшості життєвих подій (Kersting et al., 2009; Zisook et al., 2014; Jordan \& Litz, 2014);

- на відміну від великого депресивного розладу, почуття провини при ускладненому горюванні пов'язане зі стосунками з померлим і зосереджене навколо них, у той час як для клінічної депресії характерне глобальне (загальне) почуття провини (Duffy \& Wild, 2017);

- при ускладненому горюванні загальний рівень тривоги та пошук соціальної підтримки нижчі, порівняно з великим депресивним розладом (Kersting et al., 2009);

- незважаючи на загальне зниження соціальної активності, людина, проживаючи процес горювання, зберігає зацікавленість до спогадів про померлого та діяльності, що була пов'язана з ним, на відміну від загального пригнічення зацікавленості при великому депресивному розладі. Горюючи, люди іноді навмисно фокусуються на цих спогадах, а у низці культур ці спогади викристалізовуються у позитивний образ померлого;

- при ПТСР думки про померлих, як правило, мимовільні й інтрузивні та зосереджені на самому випадку смерті, тоді як при ускладненому горюванні думки про померлих як мимовільні, так і добровільні, та супроводжуються позитивними спогадами про час, проведений спільно (Jordan \& Litz, 2014);

- інтрузивні спогади при ускладненому горюванні, зазвичай, не пов'язані зі специфічними травматичними тригерами (запах, звук, колір тощо), які розкривають зміст пережитих травматичних подій і не супроводжуються відчуттям загрози, як при ПТСР, а тригеруються широким спектром нагадувань про померлого (Duffy \& Wild, 2017);

- інтрузивні спогади при стійкому горюванні рідше супроводжуються тривогою, дисфорією та гіперзбудли- 
вістю, ніж при ПТСР (Boelen et al., 2010; Jordan \& Litz, 2014);

- флешбеки й нічні жахи зустрічаються рідше, ніж при ПТСР (Shear et al., 2005; Rosner et al., 2011; Arizmendi \& O’Connor, 2015).

Попри важливість якісної диференційної діагностики, при обранні методів психологічної допомоги людям, які переживають ускладнене горювання, необхідно враховувати чинники ризику виникнення цього патологічного стану й інші «модифікуючі чинники» (елементи досвіду або зовнішнього середовища, які безпосередньо не мають причинно-наслідкового зв'язку з виникненням тих чи інших порушень, але впливатимуть на вірогідність їх появи), що сприятимуть розвитку ускладненого горювання. Результати досліджень указують на те, що різні стратегії лікування можуть бути використані з метою досягнення кращої ефективності для різних клінічних синдромів, що розвиваються у людей, які зазнали тяжкої втрати (Boelen, van den Bout \& de Keijser, 2003). Водночас висвітлені у науковій літературі профілактичні заходи переважно зосереджені на конкретних групах ризику щодо розвитку ускладненого горювання (наприклад, батьки, які втратили дітей, чи особи, в анамнезі яких зафіксовано спроби суїциду), але через недостатню кількість досліджень використовувати їх як загальнорекомендовані заходи психосоціальної допомоги у роботі з людьми, які пережили тяжку втрату, зарано (Wittouck et al., 2011). Саме тому психосоціальні інтервенції при роботі з ускладненим горюванням повинні відбуватися у контексті та з урахуванням:

1) соціальних і культурних аспектів середовища індивіда;

2) часу, що минув від моменту втрати;

3) тривалості симптомів, що робить важливою та іноді недооціненою диференційну діагностику цього стану й оцінку прогресу психологічних чи психотерапевтичних втручань. 


\section{Висновки}

Результати аналізу літератури показали, що переживання втрати значимої людини є природним процесом зцілення людини. Водночас цей процес є складною сукупністю змін мислення, емоційного реагування, поведінки й опанування травматичного досвіду, що вимагає від людини та їі оточення залучення ресурсів. Складність адаптації на шляху відновлення полягає в тому, що інші життєві виклики та попередній життєвий досвід людини (досвід стосунків, прив'язаності, сформованих глибинних переконань і життєвих правил на їх основі) впливають на прояви горювання. Приймаючи смерть значимої людини без хибних інтерпретацій та опанувавши емоційний і тілесний дискомфорт, вона долає труднощі / перешкоди майбутнього життя у соціальній чи іншій діяльності.

Водночас відмова від подолання життєвих завдань чи ригідна фіксація на одному з них або на певній стадії робить нормальний процес горювання хворобливим і патологічним. Цей стан отримав клінічне визначення як «ускладнене горювання» й був віддиференційований з-поміж низки інших проблем психічного здоров'я, які можуть виникнути після втрати близької людини, таких як клінічна депресія, ПТСР, тривожні розлади чи інші психосоматичні реакції.

Перспективу подальших досліджень убачаємо в адаптації й валідизації скринінгових методик оцінки ускладненого горювання в Україні та розробці навчально-тренінгових програм, спрямованих на розширення фахових знань і компетентностей щодо діагностики й диференційної діагностики ускладненого горювання серед фахівців сфери психічного здоров'я.

\section{Література}

Аврамчук О. Лікування ускладненого горювання та реакції на втрату. Форум психіатрї̈ та психотерапї̈: наук.-практ. журнал. Львів : УСП, 2018. Т. 11. С. 22-23. 
Диса О. В., Василюк О. Л. Шляхи подолання особистістю синдрому втрати. Особистість у кризових уловах та критичних ситуа иіях життя: Збірник наукових праць / За ред. С. Б. Кузікової, I. М. Щербакової. Суми : Вид-во СумДПУ імені А. С. Макаренка, 2016. C. 244-248.

Лім М. І. Переживання горя, робота з горем. Вісник Національної академії оборони: Збірник наукових праць Наи. ун-ту оборони України іл. Івана Черняхівського / За ред. В. В. Стасюк та ін. Київ : НУОУ, 2010. Вип. 5 (18). С. 162-166.

Линдеманн Э. Клиника острого горя. Психология элоиий. Тексты / Под ред. В. К. Вилюнаса, Ю. Б. Гиппенрейтер. Москва : Изд-во Моск. ун-та, 1984. $288 \mathrm{c.}$

Наугольник Л. Б. Особливості переживання кризи горя. Проблели особистості в освітньолу просторі держави: Матеріали круглого столу. Львів : Львівський державний університет внутрішніх справ, 2015. С. 158-162.

Онищенко Н. В. Горе як реакція постраждалого на втрату. Проблели кризової психологї: Збірник наукових праць. Харків : НУЦЗУ, 2012. Вип.12. Ч. II. С. 33-39.

Arizmendi, B. J., \& O'Connor, M.-F. (2015). What is «normal» in grief? Aust Crit Care. Retrieved from http://dx.doi.org/10.1016/j. aucc.2015.01.005.

Beckett, C., \& Dykeman, C. (2017). A metatheory of grief: Implications for counselors. VISTAS Online. Retrieved from https://www.counseling.org/docs/default-source/vistas/Metatheory_of_Grief.pdf.

Boelen, P. A., van den Bout, J., \& de Keijser, J. (2003). Traumatic grief as a disorder distinct from bereavement-related depression and anxiety: A replication study with bereaved mental health care patients. J. Psychiatry, 160, 1339-1341.

Boelen, P. A., \& Prigerson, H. G. (2007). The influence of symptoms of prolonged grief disorder, depression, and anxiety on quality of life among bereaved adults: a prospective study. Eur Arch Psychiatry Clin Neurosci, 257 (8), 444-452.

Boelen, P. A., van de Schoot, R., van den Hout, M. A., de Keijser, J., \& van den Bout, J. (2010). Prolonged grief disorder, depression, and posttraumatic stress disorder are distinguishable syndromes. J. Affect. Disord., 125, 374-378. Retrieved from http://dx.doi. org/10.1016/j. jad.2010.01.076.

Bonanno, G. A., Neria, Y., Mancini, A., et al. (2007). Is there more to complicated grief than depression and posttraumatic stress disorder? A test of incremental validity. J.Abnorm. Psychol, 116 (2), 342-351.

Bowlby, J. (1980). Loss: Sadness and depression. Attachment and loss, Vol. 3. New York, NY : Basic Books. 
Bryant, R., Kenny, L., Joscelyne, A., Rawson, N., Maccallum, F., Cahill, C., et al. (2014). Treating prolonged grief disorder: a randomized clinical trial. JAMA Psychiatry, 71, 1332-1339. Retrieved from http://dx.doi.org/10.1001/jamapsychiatry.2014.1600.

Cochran, S. (2006). Struggling for sadness: A relational approach to healing men's grief. In M. Englar-Carlson \& M. A. Stevens (Eds.). In the room with men: A casebook of therapeutic change. Washington, DC : American Psychological Association. P. 91-107.

Dell'Osso, L., Carmassi, C., Mussetti, L., Socci, Ch., Shear, M. K., Conversano, C., Maremanni, I., Perugi, G. (2012) Lifetime mood symptoms and adult separation anxiety in patients with complicated grief and/or post-traumatic stress disorder: A preliminary report. Psychiatry Research, 198, 436-440. Retrieved from http://dx.doi. org/10.1016/j.psychres.2011.12.020.

Duffy, M., \& Wild, J. (2017). A cognitive approach to Persistent Complex Bereavement disorder (PCBD). The Cognitive Behaviour Therapist, 16 (special issue - invited paper), 1-19. Retrieved from http:// dx.doi.org/10.1017/S1754470X17000034

Guldin, M. (2015). Incidence of Suicide Among Persons Who Had a Parent Who Died During Their Childhood A Population-Based Cohort Study. JAMA Psychiatry, 72 (12), 1227-1234.

Jordan, A. H., \& Litz, B. T. (2014). Prolonged Grief Disorder: Diagnostic, Assessment, and Treatment Considerations. Professional Psychology: Research and Practice, 45 (3), 180-187.

Kersting, A., Kroker, K., Horstmann, J., Ohrmann, P., Baune, B. T., Arolt, V., \& Suslow, T. (2009). Complicated grief in patients with unipolar depression. J.Affect. Disord., 118, 201-204. Retrieved from http://dx.doi.org/10.1016/j.jad.2009.01.033.

Lichtenthal, W. G., Cruess, D. G., \& Prigerson, H. G. (2004). A case for establishing complicated grief as a distinct mental disorder in DSM-V. Clinical Psychology Review, 24 (6), 637-662.

Lundorff, M., Holmgren, H., Zachariae, R., Farver-Vestergaard, I., \& O'Connor, M. (2017). Prevalence of prolonged grief disorder in adult bereavement: a systematic review and meta-analysis. J. Affect. Disord., 212. Retrieved from https://doi.org/10.1016/j.jad.2017. 01.030 .

Maciejewski, P. K., Maercker, A., Boelen, P. A., \& Prigerson, H. G. (2016). «Prolonged grief disorder» and "persistent complex bereavement disorder», but not «complicated grief», are one and the same diagnostic entity: an analysis of data from the Yale Bereavement Study. World Psychiatry, 15 (3), 266-275. Retrieved from http://dx.doi. org/10.1002/wps.20348.

Malkinson, R. (2010). Cognitive Behavioural Grief Therapy: The ABC model of Rational-Emotion Behavour. Therapy, Psychological Topics, 
19 (2), 289-305. Retrieved from http://dx.doi.org/10.1016/j.cpr. 2004.07.002.

O’Connor, M., Lasgaard, M., Larsen, L., Johannsen, M., Lundorff, M., Farver-Vestergaard, I., \& Boelen, P. A. (2019). Comparison of proposed diagnostic criteria for pathological grief using a sample of elderly bereaved spouses in Denmark: Perspectives on future bereavement research. Journal of Affective Disorders. 251, 52-59. Retrieved from https://doi.org/10.1016/j.jad.2019.01.056.

Thompson, M. R., Whiteman, A. D., Loucks, K. D., \& Daudt, H. M. L. (2017). Complicated Grief in Canada: Exploring the Client and Professional Landscape. Journal of Loss and Trauma, 22 (7), 577-598. Retrieved from http://dx.doi.org/10.1080/15325024.2017.1358574. Prigerson, H. G., Horowitz, M. J., Jacobs, S. C., Parkes, C. M., Aslan, M., Goodkin, K., \& Maciejewski, P. K. (2009). Prolonged grief disorder: Psychometric validation of criteria proposed for DSM-V and ICD-11. PLoS Med, 6 (8). Retrieved from http://dx.doi.org/10.1371/journal.pmed.1000121.

Rosner, R., Pfoh, G., \& Kotoucova, M. (2011) Treatment of complicated grief. Eur J. Psychotraumatol, 2, 7995. Retrieved from http:// dx.doi.org/10.3402/ejpt.v2i0.7995.

Simon, N. M., Shear, M. K., Thompson, E. H., Zalta, A. K., Perlman, C., Reynolds, C. F., \& Silowash, R. (2007). The prevalence and correlates of psychiatric comorbidity in individuals with complicated grief. Comprehensive Psychiatry, 48 (5), 395-399. Retrieved from http:// dx.doi.org/10.1016/j.comppsych. 2007.05.002.

Shear, M. K., Frank, E., Houck, P. R., \& Reynolds, C. F. (2005). Treatment of complicated grief: a randomized controlled trial. JAMA, 293, 2601-2608.

Shear, M. K., Simon, N., Wall, M., Zisook, S., Neimeyer, R., Duan, N., \& Keshaviah, A. (2011). Complicated grief and related bereavement issues for DSM-5. Depress Anxiety, 28 (2), 103-117. Retrieved from http://dx.doi.org/10.1002/da.20780.

Shear, M. K., Wang, Y., Skritskaya, N., Duan, N., Mauro, C., \& Ghesquiere, A. (2014). Treatment of complicated grief in elderly persons: a randomized clinical trial. JAMA Psychiatry, 71, 1287-1295.

Shear, M. K. (2015). Clinical practice. Complicated grief. N Engl. J. Med., $372(2), 153-160$.

Shear, M. K., Reynolds, C. F., Simon, N. M., Zisook, S., Wang, Y., Mauro, C., \& Skritskaya, N. (2016). Optimizing treatment of complicated grief: A randomized clinical trial. JAMA Psychiatry, 73 (7), 685694. Retrieved from http://dx.doi.org/10.1001/jamapsychiatry. 2016.0892.

Wetherell, J. L. (2012). Complicated grief therapy as a new treatment approach. Dialogues Clin Neurosci, 14 (2), 159-166. 
Wittouck, C., van Autreve, S., De Jaegere, E., Portzky, G., \& van Heeringen, K. (2011). The prevention and treatment of complicated grief: A meta-analysis. Clinical Psychology Review, 31 (1), 69-78. Retrieved from http://dx.doi.org/10.1016/j.cpr.2010.09.005.

Worden, J. W. (2018). Grief Counselling and Grief Therapy: A Handbook for the Mental Health Practitioner. New York, NY : Springer. 5th edition, pp. $x v+293$.

Zisook, S., Corruble, E., Duan, N., Iglewicz, A., Karam, E. G., Lanuoette, N., \& Young, I. T. (2012). The bereavement exclusion and DSM-5. Depression and Anxiety, 29 (5), 425-443. Retrieved from http:// dx.doi.org/10.1002/da.21927.

Zisook, S., Iglewicz, A., Avanzino, J., Maglione, J., Glorioso, D., Zetumer, S., \& Shear, M. K. (2014). Bereavement: Course, Consequences, and Care. Current Psychiatry Reports, 16 (10). Retrieved from http:// dx.doi.org/10.1007/s11920-014-0482-8.

\section{References}

Avramchuk, O. S. (2018). Likuvannia uskladnenoho horiuvannia ta reaktsii na vtratu [Treatment of complicated grief and reaction to the bereavement]. Forum psykhiatrii ta psykhoterapii - Forum on psychiatry and psychotherapy, 11, 22-23. Lviv : USP [in Ukrainian].

Dysa, O. V., \& Vasyliuk, O. L. (2016). Shliakhy podolannia osobystistiu syndromu vtraty [Ways to overcome the syndrome of bereavement by the personality]. S. B. Kuzikova, I. M. Shcherbakova (Eds.). Osobystist u kryzovykh umovakh ta krytychnykh sytuatsiiakh zhyttia: Zbirnyk naukovykh prats - The personality in crisis conditions and critical situations of life: collection of research papers, 244-248. Sumy : Vyd-vo SumDPU imeni A. S. Makarenka [in Ukrainian].

Lim, M. I. (2010). Perezhyvannia horia, robota z horem [The experience of grief, work with grief]. V. V. Stasiuk at al. (Eds.). Visnyk Natsionalnoi akademii oborony - Newsletter of Ntional Defence Academy of Ukraine: Collection of research papers of National Defence University of Ukraine named after Ivan Cherniakhovskyi, 5 (18), 162-166. Kyiv : NUOU [in Ukrainian].

Lindemann, Je. (1984). Klinika ostrogo gorja [Symptomatology and management of acute grief]. V. K. Viljunas, Ju. B. Gippenrejter (Eds.). Psihologija jemotsij. Teksty - Psychology of emotions. Texts. Moskva : Izd-vo Mosk. un-ta [in Russian].

Nauholnyk, L. B. (2015). Osoblyvosti perezhyvannia kryzy horia [Features of the experience of the crisis of grief]. Problemy osobystosti $v$ osvitnomu prostori derzhavy - Problems of the personality in the educational space of the state: Proceedings from the round table. Lviv : LvDUVS [in Ukrainian]. 
Onyshchenko, N. V. (2012). Hore yak reaktsiia postrazhdaloho na vtratu [Grief as the reaction of the sufferer to a bereavement]. Problemy kryzovoi psykholohii - Problems of crisis psychology. Collection of research papers, 12 (II), 33-39 [in Ukrainian].

Arizmendi, B. J., \& O'Connor, M.-F. (2015). What is «normal» in grief? Aust Crit Care. Retrieved from http://dx.doi.org/10.1016/j. aucc.2015.01.005.

Beckett, C., \& Dykeman, C. (2017). A metatheory of grief: Implications for counselors. VISTAS Online. Retrieved from https://www.counseling.org/docs/default-source/vistas/Metatheory_of_Grief.pdf.

Boelen, P. A., van den Bout, J., \& de Keijser, J. (2003). Traumatic grief as a disorder distinct from bereavement-related depression and anxiety: A replication study with bereaved mental health care patients. J. Psychiatry, 160, 1339-1341.

Boelen, P. A., \& Prigerson, H. G. (2007). The influence of symptoms of prolonged grief disorder, depression, and anxiety on quality of life among bereaved adults: a prospective study. Eur Arch Psychiatry Clin Neurosci, 257 (8), 444-452.

Boelen, P. A., van de Schoot, R., van den Hout, M. A., de Keijser, J., \& van den Bout, J. (2010). Prolonged grief disorder, depression, and posttraumatic stress disorder are distinguishable syndromes. J. Affect. Disord., 125, 374-378. Retrieved from http://dx.doi. org/10.1016/j. jad.2010.01.076.

Bonanno, G. A., Neria, Y., Mancini, A., et al. (2007). Is there more to complicated grief than depression and posttraumatic stress disorder? A test of incremental validity. J.Abnorm. Psychol, 116 (2), 342-351.

Bowlby, J. (1980). Loss: Sadness and depression. Attachment and loss, Vol. 3. New York, NY : Basic Books.

Bryant, R., Kenny, L., Joscelyne, A., Rawson, N., Maccallum, F., Cahill, C., et al. (2014). Treating prolonged grief disorder: a randomized clinical trial. JAMA Psychiatry, 71, 1332-1339. Retrieved from http://dx.doi.org/10.1001/jamapsychiatry.2014.1600.

Cochran, S. (2006). Struggling for sadness: A relational approach to healing men's grief. In M. Englar-Carlson \& M. A. Stevens (Eds.). In the room with men: A casebook of therapeutic change. Washington, DC : American Psychological Association.

Dell'Osso, L., Carmassi, C., Mussetti, L., Socci, Ch., Shear, M. K., Conversano, C., Maremanni, I., Perugi, G. (2012) Lifetime mood symptoms and adult separation anxiety in patients with complicated grief and/or post-traumatic stress disorder: A preliminary report. Psychiatry Research, 198, 436-440. Retrieved from http://dx.doi. org/10.1016/j.psychres.2011.12.020.

Duffy, M., \& Wild, J. (2017). A cognitive approach to Persistent Complex Bereavement disorder (PCBD). The Cognitive Behaviour Therapist, 
16 (special issue - invited paper), 1-19. Retrieved from http:// dx.doi.org/10.1017/S1754470X17000034

Guldin, M. (2015). Incidence of Suicide Among Persons Who Had a Parent Who Died During Their Childhood A Population-Based Cohort Study. JAMA Psychiatry, 72 (12), 1227-1234.

Jordan, A. H., \& Litz, B. T. (2014). Prolonged Grief Disorder: Diagnostic, Assessment, and Treatment Considerations. Professional Psychology: Research and Practice, 45 (3), 180-187.

Kersting, A., Kroker, K., Horstmann, J., Ohrmann, P., Baune, B. T., Arolt, V., \& Suslow, T. (2009). Complicated grief in patients with unipolar depression. J.Affect. Disord., 118, 201-204. Retrieved from http://dx.doi.org/10.1016/j.jad.2009.01.033.

Lichtenthal, W. G., Cruess, D. G., \& Prigerson, H. G. (2004). A case for establishing complicated grief as a distinct mental disorder in DSM-V. Clinical Psychology Review, 24 (6), 637-662.

Lundorff, M., Holmgren, H., Zachariae, R., Farver-Vestergaard, I., \& O'Connor, M. (2017). Prevalence of prolonged grief disorder in adult bereavement: a systematic review and meta-analysis. J. Affect. Disord., 212. Retrieved from https://doi.org/10.1016/j.jad.2017. 01.030 .

Maciejewski, P. K., Maercker, A., Boelen, P. A., \& Prigerson, H. G. (2016). "Prolonged grief disorder» and «persistent complex bereavement disorder», but not «complicated grief», are one and the same diagnostic entity: an analysis of data from the Yale Bereavement Study. World Psychiatry, 15 (3), 266-275. Retrieved from http://dx.doi. org/10.1002/wps.20348.

Malkinson, R. (2010). Cognitive Behavioural Grief Therapy: The ABC model of Rational-Emotion Behavour. Therapy, Psychological Topics, 19 (2), 289-305. Retrieved from http://dx.doi.org/10.1016/j.cpr. 2004.07.002.

O’Connor, M., Lasgaard, M., Larsen, L., Johannsen, M., Lundorff, M., Farver-Vestergaard, I., \& Boelen, P. A. (2019). Comparison of proposed diagnostic criteria for pathological grief using a sample of elderly bereaved spouses in Denmark: Perspectives on future bereavement research. Journal of Affective Disorders. 251, 52-59. Retrieved from https://doi.org/10.1016/j.jad.2019.01.056.

Thompson, M. R., Whiteman, A. D., Loucks, K. D., \& Daudt, H. M. L. (2017). Complicated Grief in Canada: Exploring the Client and Professional Landscape. Journal of Loss and Trauma, 22 (7), 577-598. Retrieved from http://dx.doi.org/10.1080/15325024.2017.1358574. Prigerson, H. G., Horowitz, M. J., Jacobs, S. C., Parkes, C. M., Aslan, M., Goodkin, K., \& Maciejewski, P. K. (2009). Prolonged grief disorder: Psychometric validation of criteria proposed for DSM-V and ICD-11. 
PLoS Med, 6 (8). Retrieved from http://dx.doi.org/10.1371/journal.pmed.1000121.

Rosner, R., Pfoh, G., \& Kotoucova, M. (2011) Treatment of complicated grief. Eur J. Psychotraumatol, 2, 7995. Retrieved from http:// dx.doi.org/10.3402/ejpt.v2i0.7995.

Simon, N. M., Shear, M. K., Thompson, E. H., Zalta, A. K., Perlman, C., Reynolds, C. F., \& Silowash, R. (2007). The prevalence and correlates of psychiatric comorbidity in individuals with complicated grief. Comprehensive Psychiatry, 48 (5), 395-399. Retrieved from http:// dx.doi.org/10.1016/j.comppsych.2007.05.002.

Shear, M. K., Frank, E., Houck, P. R., \& Reynolds, C. F. (2005). Treatment of complicated grief: a randomized controlled trial. JAMA, 293, 2601-2608.

Shear, M. K., Simon, N., Wall, M., Zisook, S., Neimeyer, R., Duan, N., \& Keshaviah, A. (2011). Complicated grief and related bereavement issues for DSM-5. Depress Anxiety, 28 (2), 103-117. Retrieved from http://dx.doi.org/10.1002/da.20780.

Shear, M. K., Wang, Y., Skritskaya, N., Duan, N., Mauro, C., \& Ghesquiere, A. (2014). Treatment of complicated grief in elderly persons: a randomized clinical trial. JAMA Psychiatry, 71, 1287-1295.

Shear, M. K. (2015). Clinical practice. Complicated grief. N Engl. J. Med., $372(2), 153-160$.

Shear, M. K., Reynolds, C. F., Simon, N. M., Zisook, S., Wang, Y., Mauro, C., \& Skritskaya, N. (2016). Optimizing treatment of complicated grief: A randomized clinical trial. JAMA Psychiatry, 73 (7), 685694. Retrieved from http://dx.doi.org/10.1001/jamapsychiatry. 2016.0892.

Wetherell, J. L. (2012). Complicated grief therapy as a new treatment approach. Dialogues Clin Neurosci, 14 (2), 159-166.

Wittouck, C., van Autreve, S., De Jaegere, E., Portzky, G., \& van Heeringen, K. (2011). The prevention and treatment of complicated grief: A meta-analysis. Clinical Psychology Review, 31 (1), 69-78. Retrieved from http://dx.doi.org/10.1016/j.cpr.2010.09.005.

Worden, J. W. (2018). Grief Counselling and Grief Therapy: A Handbook for the Mental Health Practitioner. New York, NY : Springer. 5th edition.

Zisook, S., Corruble, E., Duan, N., Iglewicz, A., Karam, E. G., Lanuoette, N., \& Young, I. T. (2012). The bereavement exclusion and DSM-5. Depression and Anxiety, 29 (5), 425-443. Retrieved from http:// dx.doi.org/10.1002/da.21927.

Zisook, S., Iglewicz, A., Avanzino, J., Maglione, J., Glorioso, D., Zetumer, S., \& Shear, M. K. (2014). Bereavement: Course, Consequences, and Care. Current Psychiatry Reports, 16 (10). Retrieved from http:// dx.doi.org/10.1007/s11920-014-0482-8. 
Аврамчук Олександр. Клініко-психологічні аспекти пережсивання втрати та діагностики ускладненого горювання

\section{АНОТАЦІЯ}

У статті здійснено системний аналіз літератури щодо процесу переживання втрати й ускладненого горювання. Підкреслено, що оптимальна траєкторія відновлення після смерті значимої людини полягає в успішному вирішенні нелінійних «завдань», які ставить втрата перед людиною, й проходить із несуттєвими функціональними порушеннями та залученням ефективних копінг-стратегій і активностей, шо дають змогу в здоровий спосіб проявляти емоції, згадувати померлого й долати поточні життєві проблеми.

Узагальнено інформачію про клініко-психологічні особливості та діагностичні прояви ускладненого горювання й установлено, що стрижнем процесу ускладненого горювання є сукупність симптомів інтенсивного і стійкого сепараційного дистресу, який не призводить до опрацювання досвіду втрати, а замінюється стереотипними, повторюваними стратегіями мислення та поведінки, що посилюють психосоціальні порушення. Виокремлено діагностичні критерії, які $\epsilon$ ключовими в розділенні нормального та патологічного (ускладненого) горювання, охоплюючи інтенсивність, тривалість і комплексність симптомів. Підкреслено актуальність і складність проведення диференційної діагностики ускладненого горювання поміж інших проблем психічного здоров'я, пов'язаних із пережитою втратою. Зазначено, що через спільність клінічної картини з великим депресивним розладом $i$ посттравматичним стресовим розладом, люди з ускладненою реакцією на втрату залишаються недостатньо діагностованими або хибно діагностованими, що призводить до призначення типового лікування, яке, частково зменшуючи коморбідні симптоми, не впливає на проблеми, пов'язані з ускладненим горюванням. Узагальнено відмінності між процесом ускладненого горювання, великим депресивним розладом $i$ посттравматичним стресовим розладом, які можуть бути корисними для проведення диференційної діагностики фахівцями сфери психічного здоров'я.

Автор дійшов висновку, що існує необхідність розробки навчальнотренінгових програм, спрямованих на розширення фахових знань і компетентностей щодо діагностики й диференційної діагностики ускладненого горювання й адаптації скринінгових методик оцінки ускладненого горювання в Україні. 
Ключові слова: втрата, прочес горювання, ускладнене горювання, депресія, ПТСР.

\section{Аврамчук Александр. Клинико-психологические аспекты переживания утраты и диагностики осложненного горя}

\section{АННОТАЦИЯ}

В статье осуществлен системный анализ литературы о процессе переживания утраты и осложненного горя. Подчеркнуто, что оптимальная траектория восстановления после смерти значимого человека заключается в успешном решении нелинейных "задач», которые ставит утрата перед человеком, и проходит с несущественными функциональными нарушениями и привлечением эффрективных копингстратегий и активностей, позволяющих в здоровый способ проявлять эмоции, вспоминать умершего и преодолевать текущие жизненные проблемы.

Обобщена информация о клинико-психологических особенностях и диагностических проявлениях осложненного горя. Установлено, что сердцевиной процесса осложненного горя является совокупность симптомов интенсивного и устойчивого сепарационного дистресca, который не приводит к обработке опыта утраты, а заменяется стереотипными, повторяющимися стратегиями мышления и поведения, которые усиливают психосоциальные нарушения. Выделены диагностические критерии, которые являются ключевыми в разграничении нормального и патологического (осложненного) горя, включая интенсивность, продолжительность и комплексность симптомов. Подчеркнуто актуальность и сложность проведения дифференциальной диагностики осложненного горя среди других проблем психического здоровья, связанных с пережитой утратой. Отмечено, что через общность клинической картины с большим депрессивным расстройством и посттравматическим стрессовым расстройством люди с осложненной реакцией на утрату остаются недостаточно диагностированными или неправильно диагностированными, что приводит к назначению типичного лечения, которое, частично уменьшая коморбидные симптомы, не влияет на проблемы, связанные с осложненным горем. Обобщено различия между процессом осложненного горя, большим депрессивным расстройством и посттравматическим стрессовым расстройством, которые могут быть полезными для проведения дифференциальной диагностики специалистами сферы психического здоровья. 
Автор пришел к выводу, что существует необходимость разработки учебно-тренинговых программ, направленных на расширение профессиональных знаний и компетенций по диагностике и дифрреренциальной диагностике осложненного горя и адаптации скрининговых методик оценки осложненного горя в Украине.

Ключевые слова: утрата, процесс горевания, осложненное горевание, депрессия, ПТСР. 